\title{
Differential Influence of Demographic Factors on Job Burnout among Police Officers in Ibadan, Oyo State
}

\author{
Odedokun, Solomon Adekunle PhD
}

Department of Guidance and Counselling, University of Ibadan

\section{Doi:10.5901/mjss.2015.v6n3s1p520}

\section{Abstract}

All over the world, the police is an important arm of government which is responsible for the enforcement of law and order. No nation could excel without a well-trained and disciplined force that could protect life and property of the citizens. One fundamental problem that could militate against efficient and excellent policing is job burnout. Job burnout among police personnel most especially in Nigeria has been under-reported in research despite the effort of some researchers. Investigating job burnout is therefore important among the police officers, not only in terms of their well-being but also in terms of improving their performance in the face of peace- threatening activities that are currently threatening the co-existence of the nation. This study, therefore, investigated demographic factors (age, marital status, educational level and year of experience) and job burnout amongst police officers in Oyo state, Nigeria. The study adopted a survey research design of ex-post facto type. Multistage random sampling technique was used to select two hundred and twenty (220) police officers from the six area commands in the state. The participants responded to Maslach Burnout Inventory (MBI a 0.87) to measure their level of job burnout. Data were analysed using analysis of variance and Duncan post hoc test. Results from the analysis indicated significant differences between marital status, educational level, job tenure, age, and the concept of job burnout among the police officers. Implications and recommendations for stakeholders were discussed.

Keywords: Demographic factors, Police officers and Job burnout

\section{Introduction}

Policing job, perhaps more than any professions, not only requires absolute professionalism, but also total commitment expected to make the practitioners proactive and efficient. This becomes expedient in a multi-ethnic country like Nigeria with increase profiling of crime and peace-threatening activities, like kidnapping, ethnic crisis, armed robbery, religious crisis, extra- judicial killing, political violence, and, of recent, the Boko Haram saga. All these could exert much pressure on the personnel of the Nigeria Police.

Job burnout is one of the problems that could militate against the efficiency of the police. Job burnout is not a factor to be taken lightly as the burnout syndrome could lead to indecision, disappointments, frustration, defence strategies, loss of creativity, physical and emotional exhaustion, low productivity which could therefore be counterproductive. Police personnel experiencing job burnout cannot be at ease with himself and this could be dangerous to him and the society at large.

According to Anshel (2000), law enforcement is one of the most stressful occupations world-wide. The peculiarity of the profession also makes the practitioners to experience job-related stressors such as dealing with unlawful, often dangerous actions of citizens, abusive treatment in the workplace which eventually leads to increased rate of illness, posttraumatic stress and decreased levels of job satisfaction (Anshel, 2000; Rothmann \& Agathagelou, 2000.). Therefore, this study seeks to investigate the influence of some demographic factors (age, marital status, educational level and year of experience) on job burnout among the police officers.

\section{Literature Review}

Burnout is associated with workers in helping profession and people whose work is much more demanding of which the police is inclusive. Richelson (1980) defines burnout as a state of fatigue or frustration brought about by devotion to a cause or a way of life, or relationship that failed to produce the expected reward. Maslach and Jackson (1981) provided a more detailed definition of burnout as a syndrome of emotional exhaustion, depersonalization, and reduced personal accomplishment. This definition can be situated in police work because, according to (Aremu 1998), policing job is about human contact. From the above viewpoints in literature, it could then be deduced that stress is a major determinant of job 
burnout.

In Nigeria, a high level of stress has been observed among the working class (Ndom \& Makanjuola, 2004). Adeyemo and Ogunyemi (2005) assert that workers who are involved in personal interaction are more vulnerable to occupational stress and job burnout and this could include the police. There is the problem of image problem coupled with the harrowing climate in which they work, and in which they contend with many challenges in the course of their duties, like negative perception from the public, poor funding and mismanagement of available funds, in-fighting among senior officers for promotion and posting, decayed state of discipline, inadequate basic and continuous training of police personnel, obsolete and outdated arms and ammunition, overcrowded barracks, lack of conducive offices and basic working materials. These militate against their work performance, efficiency and effectiveness and could also endanger them emotionally and thereby, make them face serious job burnout while on duty.

Studies have been conducted on burnout and demographic factors, but not much has been done on the police, especially in Nigeria, where studies of Akinnawo (1994;1995), Aremu and Idowu (2001), Aremu and Adeyoju (2003) Aremu (1996; 1998; 2000), and others have concentrated on variables like mentoring, organizational commitment, job satisfaction, pro-social behaviours and emotional intelligence. While these studies are themselves not exhaustive, their import on the development of literature on the police work cannot be ignored. Although, these studies were carried out on different populations other than the focus of this study, attempting to investigate the influence of the constructs on the police officers, would not only boost the literature - based on the police, but also on the demographic factors. This, notwithstanding, this study seeks to investigate the influence of some demographic factors (age, marital status, educational level and job tenure) on job burnout among the police officers.

The concept of age has been identified as one of the variables that consistently predict job burnout (Maslach et al., 2001). Some researchers reported that younger employees tend to suffer more from burnout when compared to their older colleagues ( Tonder \& Williams, 2009; Collings \& Murray, 1996). Other researchers like Giebels \& Janssen, 2005; Ben-Zur \& Yagil, 2005), in their own findings reported that there is no significant relationship between age and job burnout.

As per marital status, (Maslachi et. al., 2001) reported that singles, especially men, are more exposed to burnout than married individuals, while in some studies, married employees' job burnout is reported to be higher than single ones (Russell et al., 1987). Shubin, Milnazic, \& JEnnings, (1978) was of the view that married employees in the medical profession were found to have decreased level of job burnout as compared to the single employees. In the findings of Taycan, Kutlu, Cimen, \& Aydýn (2006), they reported that job burnout is less in married employees than that of single employees. However, Gulalp, Karcioglu, Sari, \& Koseoglu, (2008) found no difference between single and married employees with respect to job burnout.

As far as job tenure is concerned, studies show that employees who stay longer on a job will have higher likelihood of suffering from job burnout (Acker, 2003; Lewig et al., 2003; Derry, Iverson, \& Walsh, 2002; ). This contradicts the findings of Holman (2002) when he opined that job tenure is negatively related to job burnout. Other studies found no significant relationship between job tenure and burnout (Giebels \& Janssen, 2005; Fujiwara, Tsukishima et al., 2003).

Academic qualification has also been found to be a significant contributor to the concept of job burnout Langemo (1990). Although some researchers have associated burnout with higher levels of education (Maslach et al. 1996) others like Smith-Stevenson and Saul, (1994) reported that workers with doctoral degree are less likely to report burnout than those with master's degree. Higher levels of burnout have previously been associated with faculty mainly involved in teaching (Dick 1992; Jackson et al. 1993).

\section{Research Objectives}

In view of the above review, the present research studied the role of age, marital status, educational level and job tenure of the police officers in relations to the concept of job burnout among the officers in Oyo state. The study integrated previous findings to empirically form the framework upon which further knowledge on demographic and policing would be advanced.

\section{Research Questions}

The following research questions were raised in order to achieve the purpose of the study.

$\mathrm{H}_{01}$ : There is no significant difference in the job burnout of police officers as far as their age is concerned.

$\mathrm{H}_{\mathrm{o} 2}$ : There is no significant difference in the job burnout of police officers as far as their marital status is concerned. $\mathrm{H}_{03}$ : There is no significant difference in the job burnout of police officers as far as their job tenure is concerned. 
$\mathrm{H}_{04}$ : There is no significant difference in the job burnout of police officers as far as their academic qualification is concerned.

\section{Methodology}

\subsection{Research Design}

This study adopted a descriptive survey research design using the ex-post facto type. Ex-post type was defined by Kerlinger and Lee (2000) as a systematic empirical inquiry in which the researcher does not have direct control on the independent variables because their manifestation have already occurred or were present in the participants prior to the period the researcher goes to the field.

\subsection{Participants}

This study adopted a descriptive survey research design using the ex-post facto type. The Oyo state police command has about 6000 officers out of which two hundred and twenty (220) police officers were randomly selected. The participants involved forty eight female officers representing $21.8 \%$ and one hundred and seventy two male officers representing $78.1 \%$. The ages of the respondents range from 27 years to 49 years with mean and standard deviation of ages as 32 years and 4.24 respectively.

\subsection{Instrumentation}

Maslach Burnout Inventory was used to measure the officer's job burnout. This scale has 22 items to be responded to on 5 - point scale : "never" (1) "a few times a year" (2) "a few times a month"(3), "once a week"(4) "everyday"(5). The items are distributed in three dimension: emotional exhaustion (feelings of being emotionally sapped), depersonalization (feelings of impersonal response towards recipients of the service) personal accomplishment (diminished feelings of competence and success in working with people). The instrument was reported to have alpha reliability co-efficient of 0.73. The internal consistency of the scale was established by this study and it returned a Cronbach coefficient alpha of 0.87. Three of the items are: 'I feel burned out from my work'; 'I feel frustrated by my job'; and 'I feel like I am at the end of the rope'.

\subsection{Procedure}

The participants were administered Maslach Burnout Inventory along with a bio-data form that included their age, marital status, educational level and year of experience. The consent of the police authority and the officers involved in the study was sought before the distribution of the questionnaire.

\section{Results}

Significant differences were found among marital status, educational level, job tenure, age, and job burnout of the police officers. As such, $\mathrm{H}_{01}: \mathrm{H}_{02}: \mathrm{H}_{03}$ : $\mathrm{H}_{04}:$ were rejected

\section{Table 3:}

\section{F Sig}

ANOVA Age 2.1400 .036

Marital status 3.2560 .031

Job tenure 2.1140 .001

Academic Qualification 1.227 0.012

Duncan Post Hoc test was done on marital status, age, academic qualification, and job tenure. The table below reveals the results 
Duncan Post Hoc Test showing differences in the Marital Status and Job burnout of the officers

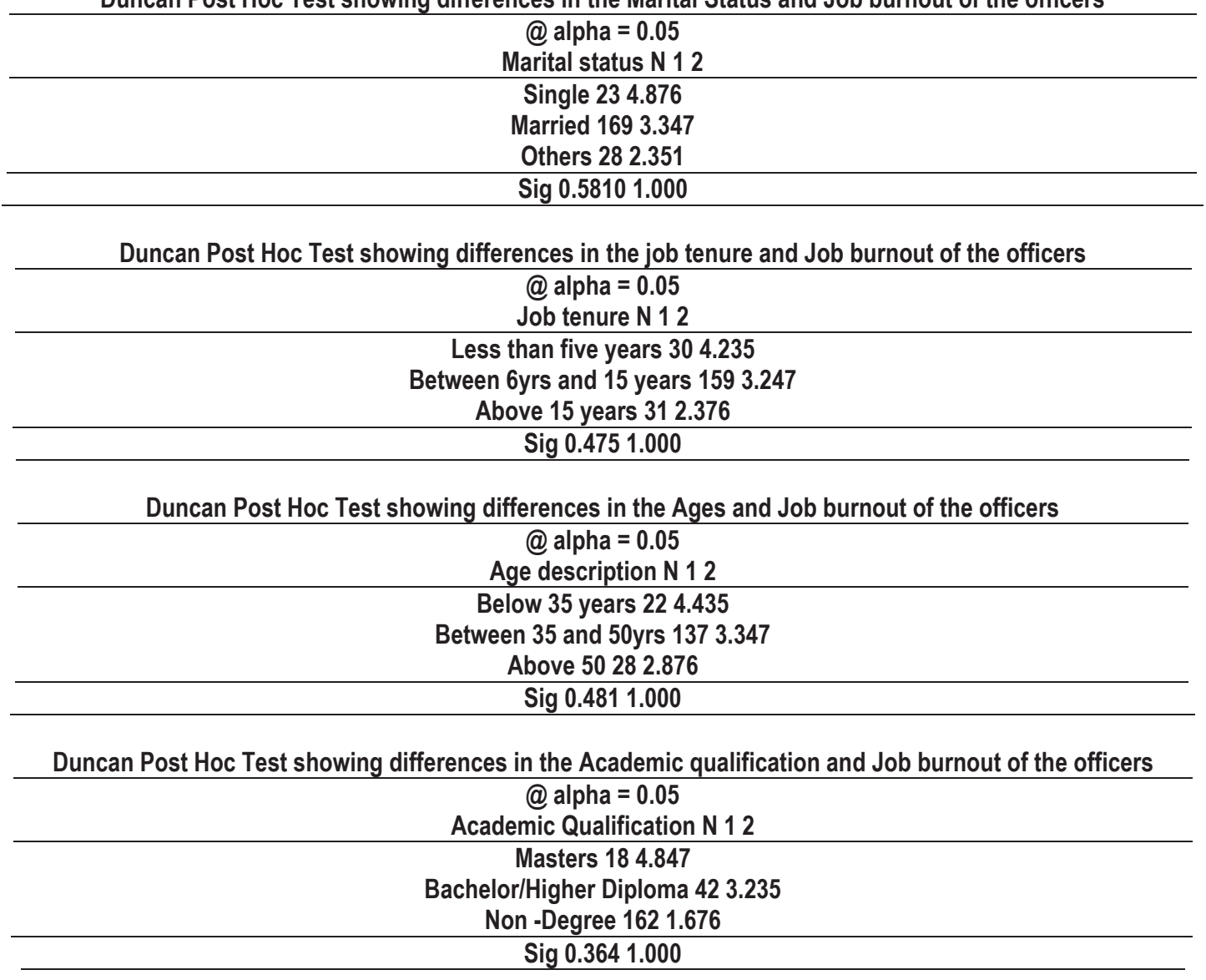

\section{Discussion}

The goal of this study was to investigate the influence of the demographic factors (Age, marital status, academic qualification and job tenure) on job burnout among police officers. The results reveal that marital status, age, academic qualification and job tenure were found to influence job burnout.

As per marital status, the results show that the single individual experiences more burnout than the married individual. This assertion corroborates the findings of (Maslach et al., 2001; Kalemoglu \& Keskin, 2006; Taycan, Kutlu, Cimen, \& Aydýn, 2006). This could be as a result of family support that the married individual enjoy at home.

Concerning job tenureship, the results showed that officers with more years in the service experience less job burnout than their counterparts that have spent few years. This contradicted the opinion shared by (Acker, 2003; Lewig et al., 2003; Derry, Iverson, \& Walsh, 2002) when they concluded in their various researches that employees who stay longer in a job will have higher likelihood of suffering from job burnout. The reason for this could be that the longer years an employee stays with the organization, the more they get used to the organization's values, missions, expectations which indirectly helps them to overcome the burden occasioned by job burnout.

Age is another factor in this study. It shows that older officers experience less job burnout compared with the younger officers. This opinion was shared by Sowmya \& Panchanatham (2011) and Kabuoh \& Anazodo (2012) who studied bank managers and found out that the younger ones experience a higher level of burnout and stress. Similarly in their research Garrosa et al. (2008) found that younger people experience burnout more often. The assumption here is that the exposure of the officers coupled with the experience must have been a source of strength with which they withstand the job burnout.

Lastly on the concept of academic qualification, it was observed that the officers with higher academic qualification experiences higher job burnout compared with officers with lower educational qualification. In support of this assertion, Cakınberk (2011) found that bank employees that held bachelor's and master's degree experienced depersonalization more often compared to non-university degree holders. This could be as a result of professional expectations, 
responsibilities and anxieties among the higher academic qualification officers as many of them are in position of authority and leadership knowing fully that uneasy lies the head that wears the crown.

\section{Implications}

The findings have a practical relevance to the Nigeria Police Force, academic scholars, psychologists, social workers, and other professionals whose call has to do with policing. The findings will help to ensure proactive approach in managing psychological burdens that police officers encounter in their day to day activities. These could be in form of developing psychological packages like social supports and stress management skills.

\section{Recommendations}

Job burnout among Nigerian police officers is yet to receive attention as a subject of research in Nigeria; hence the need to investigate job burnout among the officers of the Nigerian Police Force. The study has shown that demographic factors are great predictors of job burnout among the officers. In view of this, it is hereby recommended that a training intervention aimed at reducing and managing the problem of job burnout among the officers is most desirable. Also, interventions like social supports and coping strategies should be introduced at all levels in order to enhance the capacity of police members to cope with job burnout in the workplace.

The Nigeria Police Force leadership especially the Police Commission, which is saddled with the responsibilities of recruitment, training and welfare of police officers as a matter of urgency, should ensure the establishment of counselling centres, relaxation centres, social support packages, stress management centres and other on the job policies through which strains and other psychological burdens occasioned by policing duties could be addressed and ameliorated in all the divisional headquarters, if not in all the police stations.

Lastly, job burnout as a result of excessive paper work and insufficient personal time, inadequate and delay in salary, obsolete equipments, delay in promotion, staff shortages, poor funding, inadequate basic and continuous training of police personnel, should be targets for intervention.

\section{Limitations and Future Directions}

Firstly, the study is only limited to demographic factors; other factors like psychological and sociological were not included. Also, the study is limited to only a command of the Nigeria Police Force, studying other states or zones could lead to more representative findings. It is suggested that subsequent studies on this or similar topics should extend the scope of this study

\section{Conclusion}

In conclusion, it is shown in this study that the importance of demographic factors cannot be over emphasized in the management of job burnout among the police officers. In view of this, all hands must be on deck in managing this psychological burden called 'job burnout'.

\section{References}

Acker, G. (2003). Role conflict and ambiguity: do they predict burnout among mental health service providers? Social Work in Mental Health, 1(3), 63-80.

Adekola B (2012). Work burnout experience among university non teaching staff: A gender approach. Int. J. Aca. Res. Bus. Soc. Sci., (1): 128-135.

Adeyemo, D.A. and. Ogunyemi, B (2005) "Emotional Intelligence and Self-Efficacy as Predictors of Occupational Stress among Academic Staff in a Nigerian University". Retrieved Sept. 25,2007 from http://www/weleadinlearning.org/

Ahola, K., Honkonen, T., Isometsä, E., Kaolimo, R., Nykyri, E., Koskinen, S., et al. (2006). Burnout in the general population: Results from the Finnish Health 2000 Study. Social Psychiatry and Psychiatric Epidemiology, 41, 11-17

Akinnawo, E.O. (1994) Determinants of job and life satisfaction of Nigeria Police Officers. Ife Psychologia: An international Journal, 2,2, 275-284.

Akinnawo, E.O. (1995) Occupational Stress, manifested Psychopathology and social support among Nigerian police Officers. Unpublished Ph.D. thesis, University of Ibadan, Ibadan.

Angerer, J. M. (2003). Job burnout. Journal of Employment Counselling, 40(3), 98-107. 
Anshel, M.H. (2000) A conceptual model and implications for coping with stressful events in police work. Criminal Justice and Behavior, 27, 375-400.

Antoniou, A. S., Polychroni, F., \& Vlachakis, A. N. (2006). Gender and age differences in occupational stress and professional burnout between primary and high school teachers in Greece. Journal of Managerial Psychology, 21(7), 682-690.

Aremu, A.O. and Adeyoju, C.A. (2003). Job commitment, job satisfaction and gender as predictors of mentoring in the Nigeria police policing', An International Journal of police strategies \& management, Vol.26 No.3, pp. 377-85

Aremu, A.O. and Idowu, E. (2001) "Impact of some Demographic variables on job satisfaction of women police in Ibadan", Nigeria journal of Applied psychology, Vol.6 Nos. 1, 2, pp.144-152

Aremu, O. (1998), Enhancing job satisfaction of Nigeria police", Nigeria journal of Applied psychology, Vol.4 No. 1, pp. 44-48

Aremu, A.O. (1996) Differential efficacy of two psychological intervention programmes in the improvement of self-image of police officers in Nigeria. African Journal for the Psychological study of social Issues. 3, 1, 147-159.

Aremu (2014) Policing and Terrorism: Challenges and Issues in Intelligence. Ibadan. Stirling Holding

Bakkar, A.B., \& Schaufeli, W.B. (2000). Burnout contagion processes among teachers. Journal of Applied Psychology, 30, $2289-2309$

Bauer, J., Stamm, A., Virnich, K., Wissing, K., Müller, U., Wirsching, M., \& Schaarschmidt, U. (2006) Correlation between burnout syndrome and psychological and psychosomatic symptoms among teachers. International Archives Occupational and Environmental Health, 79(3), 199-204.

Ben-Zur, H., \& Yagil, D. (2005). The relationship between empowerment, aggressive behaviours of customers, coping and burnout. European Journal of Work and Organizational Psychology, 14(1), 81-100.

Brewer, E. W., \& Shapard, L. (2004). Employee burnout: A meta-analysis of the relationship between age or years of experience. Human Resource Development Review, 3, 102.

Burke, R.J., \& Greenglass, E.R. (2001). A longitudinal study of progressive phases of psychological burnout. Journal of Health and Human Resources Administration, 13(4), 390-408.

Burke, R. J. (1994). Stressful events, work-family conflict, coping, psychological burnout, and well-being among police officers. Psychological Reports, 75, 787-800.

Byrne, B. M. (1991). Burnout: Investigating the impact of background variables for elementary, intermediate, secondary and university educators. Teaching and Teacher Education 7:197- 209.

Cakınberk A (2011) Studying the relationship between employees'occupational burnout levels and satisfaction of life: A research in private banks African Journal of Business Management Vol. 5(16), pp. 6825-6838.

Carlson, B.C., \& Thomson, J.A. (1995) Job burnout and job leaving in public school teachers implications for stress management. International Journal of Stress Management,2, 15-29

Clarkson, G. P., \& Hodgkinson, G. P. (2007). What can occupational stress diaries achieve that questionnaires can't? Personnel Review, $36(5), 684-700$.

Collings, J.A., \& Murray, P.J. (1996). Predictors of stress amongst social workers: An empirical study. British Journal of Social Work, 26(3), 375-387.

Cordes, C.L., \& Dougerthy, T.W. (1993). A review and integration of research on job burnout. Academy of Management Review, 18(4), 621-656.

Deery, S., Iverson, R., \& Walsh, J. (2002) Work relationships in telephone call centres: Understanding emotional exhaustion and employee withdrawal. Journal of Management Studies, 39(4), 471-496.

Dick, M.J. (1992). Burnout in doctorally prepared nurse faculty. Journal of Nursing Education, 31 (8), 341-346.

Dormann, C., \& Zapf, D. (2004). Customer-related social stressors and burnout. Journal of Occupational Health Psychology, 9(1), 61-82.

Etzion, D. (1984). Moderating effect of social support on the stress-burnout relationship. Journal of Applied Psychology, 69, 615-622.

Flecther, B. (1988). The Epidemiology of Occupational Stress. In Causes, coping and

Consequences of Stress at Work, eds. C. L. Cooper and R. Payne. Chichester, UK: John Wiley.

Freudenberger, H. J., \& Richelson, G. (1980). Burn-Out: The High Cost of High Achievement. New York: Anchor Press Doubleday and Co.

Fujiwara, K., Tsukishima, E., Tsutsumi, A., Kawakami, N., \& Kishi, R. (2003). Interpersonal conflict, social support, and burnout among home care workers in Japan. Journal of Occupational Health, 45(5), 313- 320.

Garrosa, E., Moreno-Jime'nez, B., Liang, Y. \& González, J.L. (2008) The relationship between socio-demographic variables, job stressors, burnout, and hardy personality in nurses: an exploratory study. International Journal of Nursing Studies, 45, 418-427.

Giebels, E., \& Janssen, O. (2005). Conflict stress and reduced well-being at work: The buffering effect of third party help. European Journal of Work and Organizational Psychology, 14(2), 137-156.

Gillespie, D.F. \& Numerof, R.E. (1991). Burnout among health service providers. Administration and Policy in Mental Health, 18, 161-71.

Gulalp B, Karcioglu O, Sari A, Koseoglu Z (2008) Burnout: need help? Journal of Occupational Med Toxicology. 3:32.

Gurbuz, H., Tutar, H., \& Baspinar, N.O. (2007). Burnout Levels of Executive Lecturers: A Comparative Approach in Three Universities, Sosyal Bilimler Dergisi, 18, 65-85.

Hawkins, H. (2001). Police officer burnout: A partial replication of Maslach's Burnout Inventory. Police Quarterly, 4(3), 343-360.

Hind, R. R., S. M. Dornbusch and W. R. Scott. (1974). A theory of evaluation applied to a university faculty. Sociology of Education 47:114- 128.

Holman, D., Chissick, C., \& Totterdell, P. (2002). The effects of performance monitoring on emotional labor and well-being in call centers. Motivation and Emotion, 26(1), 57-81 
Jackson, R. A., C. W. Barnett, G. V. Stajich and J. E. Murphy. 1993. An analysis of burnout among school of pharmacy faculty. American Journal of Pharmaceutical Education 57:9- 17.

Johnson, L.B. (1991). Job strain among police officers: Gender comparisons. Police Studies, 14(1), 12-16.

Kabuoh, M.N., \& Anazodo, LB. (2012). Burnout syndrome among bank workers (Case of First Bank PLC and Access Bank PLC Isolo Lagos Nigeria), Babcock Journal of Management and Social Sciences, 10(1), 289-310.

Kalemoglu M, Keskin O (2006). Evaluation of stress factors and burnout in the emergency department [in Turkish]. Ulus Travma Derg ;8:215-9.

Kellinger, F. N. and Lee, H. B. 2000. Foundation of behavioural research (4th Edition). Florience, KY: Thompson Learning.

Kop, N., Euwema, M. C., \& Schaufeli, W. B. (1999) . Burnout, job stress and violent behaviour among Dutch police officers. Work \& Stress, 13(4), 326-340.

Langemo, D. K. (1990). Impact of work stress on female nurse educators. IMAGE: Journal of Nursing Scholarship 22:159-162.

Lavrova, K., \& Levin, A. (2006). Burnout Syndrome: Prevention and Management. Handbook for workers of harm reduction programs. Central and Eastern European Harm Reduction Network, 1-57. Retrieved November 10, 2010, from http://www.aidsactioneurope. org.tions/190.pd

Lewig, K.A., \& Dollard, M.F. (2003). Emotional dissonance, emotional exhaustion and job satisfaction in call centre workers. European Journal of Work and Organizational Psychology, 12(4), 366-39

Maslach, C., \& Jackson, S. (1981). MBI: Maslach Burnout Inventory. Palo Alto, CA; Consulting Psychologists Press

Maslach, C., \& Jackson, S. E. (1986) Maslach Burnout Inventory: Manual research edition. Palo Alto, CA: University of California, Consulting Psychologists Press.

Maslach, C., Schaufeli, W.B. \& Leiter, M.P. (2001). Job Burnout. Annual Review of Psychology, 52(1), $397-422$.

Maslach, C., Schaufeli, W. B. \& Leiter, M. P. (2001). Job burnout. In S. T. Fiske, D. L. Schacter \& C. Zahn-Waxler (Eds.), Annual Review of Psychology, 52, 397-422.

Ndom, R.J. \&Makanjuola, A. B (2004). Perceived stress factors among resident doctors in a Nigeria teaching hospital. West African Journal of Medicine 23(3),232-235. .

Numerof, R. E., \& Abrams, M. N. (1984). Sources of stress among nurses: An empirical investigation. Journal of Human Stress, 10, 88 100.

Rothmann, S. \& Agathagelou, A.M. (2000) Die verband tussen lokus van beheer en werkstevredenheid by senior polisiepersoneel Tydskrif vir Bedryfsielkunde, 26 (2), 20-26.

Russell, D. W., Altmaier, E., \& Van Velzen, D. (1987). Job-related stress, social support and burnout among classroom teachers. Journal of Applied Psychology, 3(2), 269-274.

Ryan, W. (1971). Blaming the Victim, Pantheon Books, New York.

Schaufeli, W. B. \& Buunk, B. P. (2003). Burnout: An overview of 25 years of research and theorizing. In M.J. Schabracq, J.A.M. Winnubst, \& Cooper, C.L. (Eds.) The handbook of work and health psychology. New York: Wiley \& Sons.

Schaufeli, W. B., \& Enzmann, D. (1998). The burnout companion to study and practice: A critical analysis. London, UK: Taylor \& Francis.

Schulz, R., Greenley, J.R., \& Brown, R. (1995). Organization, management, and client effects on staff burnout. Journal of Health and Social Behaviour, 36(4), 333-345.

Sewell, J.D. (1983). The development of a criticallife events scale for law enforcement. Journal of Police Science and Administration. 11, 109- 116.

Shubin, Seymour BS, Milnazic, Kim; Jennings, Eugene E.(1978) Burnout: The Professional hazard you face in Nursing Research. Nursing 1978; 8(9): 22-7.

Siwach, S. (2001) Extent and existence of stress and burnout stress syndrome in police The Indian Police Journal. October- December, 2001.

Smith-Stevenson, R. \& Saul, C. E. (1994). An investigation into burnout among Mississippi high school principals. 9-11 November. Paper presented at the annual meeting of the mid-south educational research association. Nashville, TN.

Sowmya, K.R., \& Panchanatham, N., (2011)a, "Employees' perception about organizational politics in banking sector" in International Journal of Research in Commerce and Management, Issue No 2 (February), Volume 2, Pg. 27-31.

Tang, C.S.K., Au, W.T., Schwarzer, R. \& Schmitz, G. (2001). Mental health outcomes of job stress among Chinese teachers: Role of stress resource factors and burnout. Journal of Organizational Behavior, 22(8),887-901.

Taycan O, Kutlu L, Cimen S, Aydin N (2006) Relation between sociodemographic characteristics depression and burnout levels of nurse working in university hospital. Anatolian J Psychiatry 2006;7:100-8.

Tonder, C.L.V., \& Williams, C. (2009). Exploring the origins of burnout among secondary educators. SA Journal of Industrial Psychology, 35(1), 1-15

Westman, M., and Etzion, D. (1995). Crossover of stress, strain and resources from one spouse to another. Journal of Organizational Behavior, 16, 169-181. 